\title{
PENDIDIKAN KESEHATAN TENTANG KEBUTUHAN DASAR ABRAHAM MASLOW DI SMA YP MANTRA BANYUASIN
}

\author{
Trilia $^{1}$, Dwi Rahma Purnama Sari ${ }^{2}$ \\ ${ }^{1}$ Program Studi D3 Keperawatan STIKes Muhammadiyah Palembang \\ ${ }^{2}$ Mahasiswa D3 Keperawatan STIKes Muhammadiyah Palembang \\ Email: triliawm13@gmail.com¹,drps.rahma@gmail.com²
}

\begin{abstract}
ABSTRAK
Setiap manusia memiliki kebutuhan dasar yang memerlukan pemenuhan, remaja memiliki tingkah laku yang khas untuk memenuhi kebutuhan tersebut. Apabila ada kebutuhan yang tidak terpenuhi, maka akan menimbulkan berbagai bentuk penyimpangan tingkah laku bagi individu yang bersangkutan. sehingga apabila kebutuhan dasar tidak terpenuhi maka akan mengakibatkan timbulnya rasa tidak puas, menjadi frustasi dan terhambatnya pertumbuhan serta perkembangan sikap positif terhadap lingkungan dan diri siswa. Untuk itu perlu dilakukan berbagai upaya oleh semua pihak yang terkait, seperti orang tua, guru/sekolah untuk memenuhi kebutuhan remaja tersebut. Tujuan program ini : mengedukasi pemahaman guru dan siswa tentang Kebutuhan Dasar Abraham Maslow di Sekolah Menengah Atas Yayasan Pendidikan (SMA YP) Mantra Mariana Kecamatan Banyuasin I Propinsi Sumatera Selatan. Metode : yang digunakan dengan memberikan pendidikan kesehatan menggunakan metode penyuluhan. Kegiatan dilaksanakan pada bulan April 2019 dengan melibatkan 10 guru dan siswa kelas X sampai kelas XI yang berjumlah 38 siswa. Guru dan siswa diberikan pemahaman tentang 5 Tingkatan kebutuhan dasar Abraham Maslow yang wajib dilaksanakan di sekolah, meliputi pemenuhan kebutuhan fisiologis, rasa aman nyaman, kasih sayang dan penerimaan, harga diri dan pemenuhan kebutuhan aktualisasi diri. Hasil : Semua guru dan siswa mendapatkan pendidikan kesehatan kebutuhan dasar Abraham Maslow. Kesimpulan : Setelah dilakukan edukasi guru dan siswa memahami pentingnya pemenuhan kebutuhan dasar siswa selama berada di sekolah. Saran : diharapkan guru dan penyelenggara pendidikan dapat memfasilitasi pemenuhan kebutuhan dasar siswa di sekolah.
\end{abstract}

Kata Kunci: Kebutuhan dasar, pengetahuan dan sikap siswa

\begin{abstract}
Every human being has basic needs that require fulfillment, adolescents have unique behavior to meet those needs. If there are needs that are not met, then it will cause various forms of behavior deviation for the individual concerned. so that if basic needs are not met it will lead to the emergence of dissatisfaction, frustration and stunted growth and the development of positive attitudes towards the environment and students' self. Therefore it is necessary to do various efforts by all parties concerned, such as parents, teachers / schools to meet the needs of these adolescents. The purpose of this program: educating teachers and students' understanding of Abraham Maslow's Basic Needs in Mantra Mariana Foundation High School (SMA YP), Banyuasin I District, South Sumatra Province Method: used by providing health education using counseling methods. The activities will be held in April 2019, involving 10 teachers and students from grade X to grade XI with a total of 38 students. Teachers and students an understanding of the 5 basic levels of Abraham Maslow's basic
\end{abstract}


needs that must be carried out at school includes the fulfillment of physiological needs, security, comfort, affection and acceptance, self-esteem and finally self-actualization needs. Results: All teachers and students get Abraham Maslow's basic health education needs. Conclusion: After educating the teacher and students understand the importance of meeting the basic needs of students while in school. Suggestion: It is hoped that teachers and education providers can facilitate the fulfillment of the basic needs of students at school.

Keywords: Basic needs, knowledge and attitudes of students

\section{PENDAHULUAN}

Setiap manusia memiliki kebutuhan (Fisiologis, Psikologis, dan Sosiologis) yang memerlukan pemenuhan. Semua orang berusaha dengan berbagai sikap dan tingkah laku untuk memenuhi kebutuhannya itu. Demikian pula remaja memiliki tingkah laku yang khas untuk memenuhi kebutuhan tersebut. Apabila ada kebutuhan yang tidak terpenuhi, maka akan menimbulkan berbagai bentuk penyimpangan tingkah laku bagi individu yang bersangkutan (Tarwoto, 2018). Oleh karena itu perlu dilakukan berbagai upaya oleh semua pihak yang terkait, seperti orang tua, guru/sekolah untuk memenuhi kebutuhan remaja tersebut.

Tiga jenis kebutuhan manusia tersebut juga disebut kebutuhan dasar, karena semua manusia dalam segala usia memerlukan dan membutuhkan pemenuhannya. Menurut Abraham Maslow dalam Tarwoto (2018) suatu kebutuhan dinamakan "Kebutuhan Dasar" jika memenuhi syarat berikut ini : 1. Apabila hal yang dibutuhkan itu ada/tidak terpenuhi, maka penyakit atau gangguan, 2. Apabila yang dibutuhkan itu ada/terpenuhi, maka dapat mencegah terjadinya penyakit, 3. Apabila seseorang mampu mengendalikan terpenuhinya kebutuhan tersebut, maka akan dapat menyembuhkan penyakit atau menghilangkan timbulnya gangguan pada dirinya.

Maslow dalam Tarwoto (2018) merumuskan kebutuhan manusia terdiri dari lima jenis dan berjenjang. Teorinya terkenal dengan “ Hirarki Kebutuhan” manusia. Disebut dengan hirarki, karena pemenuhan kebutuhan dilakukan secara berjenjang sesuai dengan yang lainnya untuk segera dipenuhi. Apabila kebutuhan pertama telah terpenuhi dengan baik maka ranking prioritas yang terbesar berikutnya adalah jenis kebutuhan kedua, yaitu kebutuhan rasa aman, dan seterusnya hingga kebutuhan kelima. Lima jenis kebutuhan menurut Maslow yaitu : kebutuhan fisiologis. Rasa aman nyaman, mencintai memiliki, harga diri dan aktualisasi diri.

Dari lima kebutuhan itu, kebutuhan yang mendapat perhatian lebih besar dibanding dengan kebutuhan lainnya untuk segera dipenuhi adalaah kebutuhan yang berkaitan dengan 
kebutuhan fisik kebutuhan ini juga diistilahkan dengan "'kebutuhan fisiologis" contoh dari jenis kebutuhan ini antara lain kebutuhan untuk makan, minum, pakaian, seks, udara segar, istirahat, dan sejenisnnya. Kebutuhan ini merupakan kebutuhan yang berada pada level paling utama untuk kelangsungan hidup manusia (Tarwoto, 2018)

Kebutuhan rasa aman dan tentram juga disebut dengan istilah "safety needs" rasa aman yang bersifat psikis, seperti dikatakan oleh Steers dan Porter dalam Tarwoto (2018) yaitu aman dalam bentuk lingkungan emosional. Aman berarti terbebas dari gangguan dan ancaman, serta permasalahan yang dapat mengganggu ketenangan hidup seseorang. Bebas dari ancaman yang dapat mengganggu kelangsungan hidup sehari-hari.

Kebutuhan rasa cinta dan memiliki atau "love and belongingness needs". Kebutuhan ini dapat berupa perasaan diterima oleh orang lain, merasa dirinya berguna bagi orang lain, diikutsertakan dalam kelompoknya, mengembangkan persahabatan dan sejenisnya. Orientasi pemenuhan kebutuhan ini cenderung pada terciptanya hubungan sosial yang harmonis dan kepemilikan. Jenis kebutuhan yang keempat ini juga disebut dengan "self esteem needs". Setiap manusia membutuhkan pengakuan secara layak atas keberadaanya bagi orang lain. Hak dan martabatnya sebagai manusia tidak dilecehkan oleh orang lain, bilamana terjadi pelecehan harga diri, maka setiap orang akan marah atau tersinggung. Jenis kebutuhan yang kelima ini diistilahkan dengan 'self actualization needs'. Setiap orang memiliki potensi dan potensi itu perlu pengembangan dan pengaklualisasian. Orang akan menjadi puas dan citra dirinya positif apabila dapat mewujudkan potensi - potensi yang dimiliki dengan baik. Orang akan merasa bahagia dan puas bilamana dapat mewujudkan peran dan tanggung jawabnya dengan baik. Contohnnya seorang siswa dapat berprilaku atau menampilkan diri sebagaimana layaknya seorang siswa dalam kehidupannya sehari - hari. (Steers dan Porter dalam Tarwoto, 2018). Oleh karena itu, tujuan kegiatan ini adalah untuk mengedukasi guru dan siswa agar memahami pemenuhan kebutuhan dasar siswa selama di sekolah

\section{MASALAH}

Usaha memenuhi kebutuhan bagi remaja tidaklah mudah, melainkan sangat rumit, kompleks dan bervariasi sebagai contoh kebutuhan remaja yang sering kurang memperoleh kebutuhan adalah kebutuhan akan kasih sayang dari orang tua maupun orang dewasa lainnya. Hal ini akan mengakibatkan remaja cenderung mencari penyelesaiannya sendiri dengan cara membanci orang tua, suka mencari perhatian orang lain, lebih betah berkumpul dengan teman sebayanya, kebutuhannya itu seperti gurunya, pemuka masyarakat, mencintai orang yang lebih dewasa dan sebagainya (Ali, 2016). Apabila kebutuhan dasar tidak terpenuhi maka akan 
mengakibatkan timbulnya rasa tidak puas, menjadi frustasi dan terhambatnya pertumbuhan serta perkembangan sikap positif terhadap lingkungan dan dirinya. Sebagai contoh masa remaja disebut pula sebagai masa sosial hunger (kehausan sosial), yang ditandai dengan adanya keinginan untuk bergaul dan diterima di lingkungan kelompok sebayanya/perkelompok (Mudjiran, 2017). Penolakan dari per kelompok dapat menimbulkan frustrasi dan menjadikan dia sebagai isolated dan merasa rendah diri. Namun sebaliknya apabila remaja dapat diterima oleh rekan sebayanya dan bahkan menjadi idola tentunya ia akan merasa bangga dan memiliki kehormatan dalam dirinya. Problema perilaku sosial remaja tidak hanya terjadi dengan kelompok sebayanya, namun juga dapat terjadi dengan orang tua dan dewasa lainnya, termasuk dengan guru di sekolah. Hal ini disebabkan pada masa remaja, khususnya remaja awal akan ditandai adanya keinginan yang ambivalen, di satu sisi adanya keinginan untuk melepaskan ketergantungan dan dapat menentukan pilihannya sendiri, namun di sisi lain dia masih membutuhkan orang tua, terutama secara ekonomis. Pada masa remaja juga ditandai dengan adanya keinginan untuk mencoba-coba dan menguji kemapanan norma yang ada, jika tidak terbimbing, mungkin saja akan berkembang menjadi konflik nilai dalam dirinya maupun dengan lingkungannya (Sunarto, 2015).

\section{METODE PELAKSANAAN}

Metode pelaksanaan penyuluhan ini terdiri dari sasaran, waktu, peralatan dan tahapan pelaksanaan kegiatan (prosedur) sebagai berikut: Sasaran dalam pelaksanaan edukasi ini dilakukan pada 10 orang guru dan 38 siswa kelas X dan XI SMA YP Mantra Banyuasin. Waktu pelaksanakan kegiatan di bulan April 2019 dan peralatan yang disiapkan untuk mendukung kegiatan edukasi adalah menyiapkan Satuan Acara Penyuluhan sesuai materi 5 tingkatan Kebutuhan Dasar Abraham Maslow, power point dan LCD untuk penyuluhan dan menyiapkan absensi peserta penyuluhan. Selanjutnya menyiapkan pengajuan surat izin pengabdian masyarakat pada institusi STIKes Muhammadiyah Palembang, berkoordinasi dengan dinas pendidikan dan sekolah. Pada Tahapan Pelaksanaan edukasi, untuk mendapatkan data awal, dilakukan studi pendahuluan dengan mendatangi sekolah pada tanggal 2 April 2019, diperoleh data pengetahuan guru dan siswa yang kurang tentang 5 kebutuhan dasar, selanjutnya hasil koordinasi dengan sekolah, disepakati kegiatan edukasi dilakukan pada hari kamis dan jum'at, 11dan 12 April 2019 Pukul 09.00 - 11.00 WIB. Kegiatan dilakukan 3 sesi, memberikan edukasi pada guru, siswa kelas X dan kelas XI, guru dan siswa diberi kesempatan bertanya dan berdiskusi, diakhir kegiatan dilakukan evaluasi materi untuk guru dan siswa. 


\section{HASIL DAN PEMBAHASAN}

Hasil edukasi ini menunjukkan bahwa siswa lebih memilih memenuhi kebutuhan fisiologis berupa makanan dibandingkan menyelesaikan sekolah, siswa berpendapat untuk apa berlama-lama menghabiskan waktu disekolah jika tidak menghasilkan uang, bila waktu sekolah tersebut digunakan untuk bekerja, siswa dapat membantu meringankan ekonomi keluarga. Berdasarkan hasil penelitian yang dilakukan Trilia (2018) tentang Aplikasi Teori Hierarki Kebutuhan Maslow Dalam Meningkatkan Motivasi Belajar Siswa di SMA YP Mantra Banyuasin. menunjukkan 32 responden $(35,1 \%)$ pemenuhan kebutuhan fisiologis kurang baik, diantaranya sarana toilet yang kurang memadai di sekolah. Dalam memenuhi kebutuhan fisik sekolah dapat menyediakan fasilitas, seperti: kantin bersih dan sehat, ruangan kelas yang nyaman, toilet yang bersih dengan jumlah yang memadai, waktu istirahat yang cukup untuk ke kamar kecil atau untuk minum, lingkungan belajar yang kondusif. Guru sangat memahami pentingnya memenuhi kebutuhan fisiologis tersebut, meskipun demikian diakhir edukasi para guru berjanji untuk meneruskan masukan terkait kelengkapan sarana prasarana yang berhubungan dengan kebutuhan fisiologis ini ke pihak yayasan.

Setelah mendapatkan edukasi tentang pemenuhan kebutuhan aman dan nyaman, guru memberikan respon yang positif, ke depan bersama-sama siswa berusaha membenahi kekurangan yang ada, meskipun pemenuhan kebutuhan aman dan nyaman siswa masih ada yang belum terpenuhi, dapat dilihat dari hasil penelitian Trilia (2018) bahwa ada 15 responden $(21,1 \%)$ kategori tidak baik, data yang didapat siswa tidak rajin ke sekolah karena merasa ada guru yang tidak menyenangkan dan diperlakukan tidak adil oleh guru. Terkait dengan Pemenuhan kebutuhan kasih sayang dan memiliki, hasil penelitian Trilia (2018) ada 15 responden $(21,1 \%)$ berpendapat bahwa guru mendidik siswa dengan tidak sabar, karena kesabaran guru dalam menghadapi siswa yang bermasalah dapat memberikan rasa aman dan nyaman pada siswa. Siswa juga merasa pendapat mereka sering tidak dihargai oleh teman saat berdiskusi. Untuk pemenuhan kebutuhan kasih sayang dan memiliki berikut hubungan antara guru dan siswa yang baik hendaknya: bersikap empatik, perhatian dan interest kepada siswa, sabar, adil, mau membuka diri, positif, dan dapat menjadi pendengar yang baik; memahami (kebutuhan, potensi, minat, karakteristik kepribadian dan latar belakangnya); memberikan komentar dan umpan balik yang positif dari pada yang negatif; menghargai dan menghormati setiap pemikiran, pendapat, keputusan menjadi penolong yang bisa diandalkan dan memberikan kepercayaan terhadap, sedangkan 
untuk hubungan antara siswa dengan siswa dapat dilakukan dengan cara: mengembangkan situasi yang memungkinkan terciptanya kerja sama mutualistik dan saling percaya di antara ; mengembangkan diskusi kelas; peer tutoring; mengembangkan Unit Kegiatan Siswa (UKS), himpunan jurusan, dan kegiatan lainnya.

Hasil edukasi yang berkaitan dengan Pemenuhan kebutuhan harga diri perlunya dilakukan pendekatan yang baik terhadap siswa, berdasarkan hasil penelitian Trilia (2018) didapatkan hasil 33 responden (46,5\%) kategori tidak baik karena guru sering menegur siswa didepan umum, dan ketika siswa ada masalah, guru tidak memberi solusi dan saran pada siswa. Upaya yang dapat dilakukan sekolah dalam rangka membangun rasa percaya diri seperti mengembangkann pengetahuan baru berdasarkan latar belakang pengetahuan untuk membantu memastikan keberhasilan (scaffolding); mengembangkan metode pembelajaran yang beragam; mempertimbangkan kebutuhan dan kemampuan ketika merencanakan dan melaksanakan pembelajaran, Penghargaan dari Pihak lain dengan cara: mengembangkan iklim kelas dan pembelajaran kooperatif di mana setiap dapat saling menghormati dan mempercayai, tidak saling mencemoohkan; menyelenggarakan pemilihan ketua senat/Badan Eksekutif secara terbuka; mengembangkan program penghargaan atas pekerjaan, usaha, dan prestasiyang diperoleh, mengembangkan kurikulum yang dapat mengantarkan setiap untuk memiliki sikap empatik dan menjadi pendengar yang baik, berusaha melibatkan para dalam setiap pengambilan keputusan yang terkait dengan kepentingan siswa itu sendiri. Untuk pemenuhan kebutuhan aktualisasi diri, guru harus lebih banyak mengeksplor kemampuan siswa, berdasarkan hasil penelitian Trilia (2018) didapatkan data 30 responden $(42,3 \%)$ kategori tidak baik, sebagian siswa belum difasilitasi jika mengikuti perlombaan diluar sekolah, siswa masih belum dilibatkan bersama guru dalam kegiatan diluar sekolah dan keinginan siswa untuk pengembangan minat dan bakat masih belum terfasilitasi dengan sempurna oleh sekolah. Upaya yang dapat dilakukan sekolah dalam pemenuhan kebutuhan aktualisasi diri dapat dilakukan dengan cara: memberikan kesempatan kepada para siswa untuk melakukan yang terbaik, memberikan kekebasan kepada untuk menggali dan menjelajah kemampuan dan potensi yang dimilikinya, menciptakan pembelajaran yang bermakna dikaitkan dengan kehidupan nyata, perencanaan dan proses pembelajaran yang melibatkan aktivitas metakognitif, melibatkan dalam proyek atau kegiatan "self expressive" dan kreatif. Setelah dilakukan edukasi pada guru dan siswa SMA YP Mantra Banyuasin, didapatkan data tentang pengetahuan siswa terhadap 5 tingkatan kebutuhan dasar Abraham Maslow sebagai dasar melakukan kegiatan pengabdian masyarakat dan hasil evaluasi yang didapatkan guru dan siswa memahami pentingnya 
memenuhi kebutuhan 5 tingkatan kebutuhan dasar.

\section{KESIMPULAN}

Berdasarkan hasil kegiatan dapat disimpulkan bahwa pentingnya edukasi pemenuhan kebutuhan dasar dalam meningkatkan motivasi belajar siswa terletak dalam hubungan antara kebutuhan dasar dan kebutuhan tumbuh. Sekolah hendaknya menyadari bahwa apabila kebutuhan dasar dan kebutuhan tumbuh siswa tidak dipenuhi, proses belajar mengajar dapat terganggu.

\section{SARAN}

Penyelenggara pendidikan / sekolah dan guru hendaknya memfasilitasi kebutuhan fisik dan kebutuhan dasar disekolah.

\section{UCAPAN TERIMA KASIH}

Penulis mengucapkan banyak terima kasih kepada Ketua STIKes Muhammadiyah Palembang, Ka. Unit P2M, Ka. Prodi DIII Keperawatan dan Kepala Sekolah SMA YP Mantra Banyuasin yang telah memberikan dukungan baik moril dan materil sehingga program pengabdian kepada masyarakat ini dapat terlaksana dengan baik.

\section{DAFTAR PUSTAKA}

Ali, Mohammad,.2016. Psikologi Remaja. Jakarta: Bumi Aksara.

Alisuf Sabri, 2015. Pengantar Ilmu Pendidikan. Jakarta: Proyek Pengadaan Buku Ajar Atas Biaya Dipa Universitas Islam Negeri (UIN) Syarif Hidayatullah Jakarta.

Mudjiran,. 2017. Perkembangan Peserta Didik. Padang: UNP Press.

Sunarto, 2015.Perkembangan Peserta didik. Jakarta:PT Rineka Cipta

Tarwoto, 2018. Kebutuhan Dasar Manusia dan Proses Keperawatan, Jakarta Salemba Medika

Trilia, 2018. Hubungan Pemenuhan Kebutuhan Dasar Berdasarkan Hirarki Maslow dengan Motivasi Belajar Siswa SMA, Babul Ilmi Jurnal ilmiah Multi Science Kesehatan . Volume 9, Desember 2019, Nomor 3 : halaman 344 